\title{
A LOS OCHO AÑOS DE LA GUERRA: RECUERDOS ESPAÑOLES
}

George Orwell*

1 comienzo de la guerra civil española, que alzó el telón del
conflicto actual y es uno de los acontecimientos más trágicos y más sórdidos que ha visto la Europa moderna, cumplirá ocho años el viernes próximo.

El resultado de la guerra de España se decidió fuera del país, y al cabo de un año cualquier observador realista sabía que el gobierno democrático no podía ganar a menos que hubiera un cambio radical en la situación europea. Durante la primera fase de la guerra, que duró casi un año, la lucha fue entre las tropas profesionales y los moros de Franco, por un lado, y las milicias de trabajadores y campesinos organizadas apresuradamente, por el otro.

En esta fase, el resultado fue más o menos de empate y ningún objetivo de gran importancia cambió de manos.

Franco, sin embargo, era reforzado ampliamente por las potencias del Eje mientras que el Gobierno español solo recibía esporádicos envíos de armas de la Rusia soviética y la ayuda de unos pocos miles de voluntarios extranjeros, la mayor parte refugiados alemanes. En junio de 1937, la resistencia de los vascos se hundió y el equilibrio de fuerzas se inclinó decisivamente en contra del Gobierno.

\section{LLEGA EL HAMBRE}

Sin embargo, el Gobierno mientras tanto había controlado el caos revolucionario de los primeros días, suavizado las peleas entre las distintas

* Publicado originalmente en The Observer, 16 de julio de 1944. Fecha de recepción: 1 de abril de 2016, fecha de aceptación: 12 de mayo de 2016. Sugerencia de citación: Orwell, G. "A los ocho años de la guerra: recuerdos españoles", Revista de Economía Institucional 18, 34, 2016, pp. 327-329. DOI: http://dx.doi. org/10.18601/01245996.v18n34.18 
facciones y entrenado a sus tropas inexpertas. A comienzos de 1938 tenía un ejército formidable, capaz de seguir luchando durante el año que aproximadamente duraron las reservas de comida.

El doctor Negrín y los demás dirigentes de la España fiel al gobierno eran probablemente conscientes de que no podían ganar por sí solos, pero se justificaban en seguir luchando, ya que la situación política europea podía cambiar. La guerra mundial que claramente se avecinaba podía estallar en 1938; el gobierno británico podía abandonar su política de no intervención.

Ninguna de estas cosas ocurrió, y hacia el final de 1938 los rusos retiraron su apoyo. La España fiel al gobierno llevaba tiempo sin comer, y la situación era ya de hambruna.

Mientras las fuerzas fascistas conquistaban Cataluña, un torrente de refugiados pasaba a Francia, ametrallados por aviones italianos e internados tras alambre de espino en cuanto llegaban.

A comienzos de 1939, Franco entró en Madrid y aplicó su victoria con la crueldad más absoluta. Todos los partidos políticos de izquierda fueron suprimidos e innumerables personas ejecutadas o encarceladas. Si las recientes informaciones son ciertas, medio millón de personas, el $2 \%$ de la población española, permanece en campos de concentración.

\section{LA INTERVENCIÓN DEL EJE}

La historia es repugnante por el vergonzoso comportamiento de las grandes potencias y la indiferencia general del mundo. Los alemanes y los italianos intervinieron para aplastar la democracia española, conquistar un punto clave estratégico para la guerra siguiente y, de paso, probar sus bombarderos contra poblaciones indefensas.

Los rusos repartieron una pequeña cantidad de armas y a cambio obtuvieron un máximo de control político. Los británicos y los franceses se limitaron a mirar para otro lado mientras sus enemigos triunfaban y sus amigos eran destruidos. La actitud británica es la menos perdonable, porque fue estúpida además de deshonrosa.

Era obvio desde el principio que cualquier país extranjero que proporcionara armas al gobierno español podría controlar o al menos influir en la política del gobierno. En cambio, los británicos prefirieron garantizar la victoria de Franco y Hitler, y a la vez, que el afecto y la gratitud del pueblo español fueran para Rusia y no para Gran Bretaña.

\section{LA AYUDA DE RUSIA}

Durante un año o más, el Gobierno español estuvo de hecho bajo control ruso, principalmente porque Rusia fue el único país en acudir 
en su auxilio. El crecimiento del Partido Comunista Español de unos pocos miles a un cuarto de millón de miembros fue logrado exactamente por el Partido Conservador británico.

Ha habido una fuerte tendencia a esconder estos hechos e incluso a considerar la "no intervención" de Franco como un triunfo de la diplomacia británica. Mucho mejor sería recordar siempre la verdadera historia de la guerra de España como una perfecta demostración de la estupidez y la mezquindad de la política de potencias. En verdad nada se salva de esta historia, salvo el valor de los combatientes de ambos lados y la resistencia de la población civil de la España republicana, que durante años soportó hambre y dificultades desconocidas para nosotros en los peores momentos de esta guerra. 